\title{
Why Is the Market Share of Adjustable- Rate Mortgages So Low?
}

\author{
Emanuel Moench, James Vickery, and Diego Aragon
}

Over the past several years, U.S. homebuyers have increasingly favored fixed-rate mortgages over adjustable-rate mortgages (ARMs). Indeed, ARMs have dropped to less than 10 percent of all residential mortgage originations, a near-record low. One might speculate that the decline in the ARM share has been driven by "one-off" factors relating to the financial crisis. However, a statistical analysis suggests that recent trends can largely be explained by the same factors that have historically shaped mortgage choice - most notably, the term structure of interest rates and its effects on the relative price of different types of mortgages. Supply-side factors, in particular a rise in the share of mortgages eligible to be securitized by the housing government-sponsored enterprises, also play a role in the low current ARM share.

$\mathrm{H}$ ouseholds financing a home purchase face a host of important but difficult choices. They must decide not only how much to borrow and which lender to use, but also what type of mortgage best suits their needs. This last choice has far-reaching implications — not just for borrowers, but for lenders and policymakers as well.

In the United States, the most popular form of home financing is the thirty-year level-payment fixed-rate mortgage, which may be prepaid on demand. Also common are amortizing adjustable-rate mortgages (ARMs), whose rates move with a market interest rate. ${ }^{1}$ Usually, these loans take the form of "hybrid ARMs"; they offer an initial period of two to five years at a fixed rate and then switch to an adjustable rate. ${ }^{2}$

Understanding what drives the ARM share is of substantial interest to policymakers, given the importance of residential mortgages to households' and banks' balance sheets and to the transmission of monetary policy. U.S. households owe a total of $\$ 10.2$ trillion in residential mortgage debt, representing 73 percent of total household liabilities. ${ }^{3}$

The sensitivity of this debt to short-term interest rates is important in shaping how monetary policy influences the broader economy. In countries like the United Kingdom, Canada, and Australia, where most mortgages are tied to short-term interest rates, a change in the policy interest rate by the central bank quickly shifts mortgage payments

\footnotetext{
${ }^{1}$ ARM interest rates are generally linked to a short-term constant-maturity Treasury rate or to the London interbank offered rate (Libor). The interest rate adjusts on a regular schedule (for example, once per year or once every six months) in line with the current value of the market rate.

${ }^{2}$ Shorter term fixed-rate mortgages, such as fifteen- and twenty-year loans, are also available but have a lower market share, while interest-only and negative amortization mortgages (in which borrowers make no payments of mortgage principal during the early years of the loan) gained considerable, albeit temporary, popularity during the recent housing boom.

${ }^{3}$ See Board of Governors of the Federal Reserve System, Flow of Funds Accounts, Table L.100, 2010:Q1.
} 
and cash flows for existing borrowers, potentially influencing their consumption. It also shifts the initial cost of new home loans, affecting the demand for and pricing of housing. ${ }^{4}$

In the United States, by contrast, where ARMs are less common, the cost of mortgage finance is tied more closely to long-term interest rates such as the ten-year Treasury rate, over which the central bank has less control. Thus, changes in the Fed's federal funds rate target have only an indirect effect on most mortgage interest rates. However, studies suggest that the refinancing of fixed-rate mortgages during periods of falling

\section{Understanding what drives the ARM share is of substantial interest to policymakers, given the importance of residential mortgages to households' and banks'balance sheets and to the transmission of monetary policy.}

long-term interest rates generates significant increases in household consumption. The real effects of these refinancing waves should be taken into account when forecasting the behavior of the household and housing sectors.

The mix of adjustable-rate and fixed-rate mortgages also has important risk implications for financial institutions. Fixed-rate mortgages, which generate a long-lived stream of fixed cash flows, create a "maturity mismatch" for financial institutions that are financed by demand deposits or other types of short-term debt. Fixed-rate mortgages also expose financial institutions to "prepayment risk," or the risk that borrowers will choose to prepay their mortgages. These features make fixed-rate mortgages challenging from a risk management perspective, an important reason for the high level of mortgage securitization in the United States.

In this edition of Current Issues, we study recent U.S. household mortgage trends with an eye to explaining the choices homebuyers have made between fixed-rate and adjustable-rate mortgages. The ARM share has fluctuated substantially over time, reaching highs of 60 to 70 percent in 1994 but falling significantly in recent years. Indeed, the ARM share is now near a record low: ARMs make up less than 10 percent of recent residential mortgage originations (Chart 1).

\footnotetext{
${ }^{4}$ This linkage is discussed further in Debelle (2004). Tsatsaronis and Zhu (2004) and the International Monetary Fund (2004) present evidence suggesting that macroeconomic volatility is larger in countries with a high ARM share. The United Kingdom, motivated in large part by an interest in reducing the sensitivity of U.K. household cash flows to short-term interest rates, has considered numerous approaches to increasing the share of fixed-rate mortgages (Miles 2004). See Mishkin (2007) for a further discussion of these issues from a U.S. perspective and a more general analysis of how U.S. monetary policy is transmitted through the housing market.
}

Chart 1

\section{ARM Share of Mortgages in Two Data Sets}

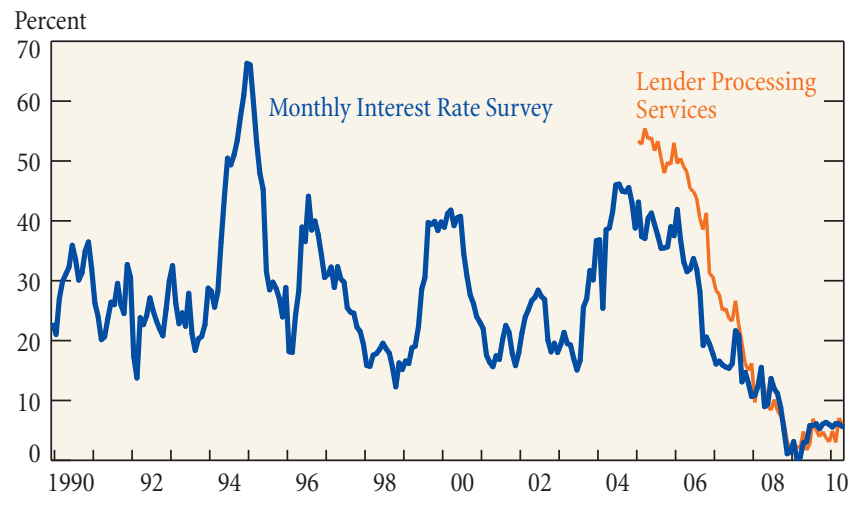

Sources: Federal Home Finance Agency, Monthly Interest Rate Survey; Lender Processing Services.

Notes: Data are monthly and cover the period from December 1989 through April 2010. Mortgage refinancings are excluded.

What accounts for these trends, particularly the striking recent decline in the ARM share? One hypothesis is that household mortgage choice in the last several years has been largely determined by institutional factors related to the financial crisis, such as the collapse of the securitized nonprime mortgage market, where adjustable-rate mortgages predominated, and the placement of Fannie Mae and Freddie Mac in conservatorship. A second and related hypothesis is that the crisis has reduced demand for adjustable-rate contracts because households have become more risk averse following the publicity given to high default rates on subprime ARMs, and the reports of "payment

\section{The ARM share has fluctuated substantially over time, reaching highs of 60 to 70 percent in 1994 but falling significantly in recent years.}

shock" associated with interest rate resets on ARMs. A third hypothesis is that the low ARM share has been driven by the same long-run historical factors that shaped mortgage choice in earlier periods, such as the term structure of interest rates and its effects on the relative price of different types of mortgages.

Using a simple econometric model, we find that the low ARM share is largely consistent with long-run historical patterns in household mortgage choice-namely, that households tend to prefer fixed-rate mortgages when long-term interest rates are low relative to recent short-term rates.

Supply-side effects associated with the financial crisis also seem to have played a role in shaping recent household mortgage choices. As part of our analysis, we examine how the ARM share 


\section{ARM Share of Originations across Mortgage Submarkets}

\begin{tabular}{|c|c|c|c|c|c|c|c|c|c|c|c|c|}
\hline \multirow{2}{*}{ anel A: All Mortgas } & \multicolumn{6}{|c|}{ Volume Weighted } & \multicolumn{6}{|c|}{ Value Weighted } \\
\hline & 2005 & 2006 & 2007 & 2008 & 2009 & 2010 & 2005 & 2006 & 2007 & 2008 & 2009 & 2010 \\
\hline Government & 9.5 & 4.6 & 3.5 & 2.7 & 1.9 & 4.4 & 10.1 & 5.2 & 4.0 & 3.1 & 2.3 & 4.9 \\
\hline Nonprime & 52.5 & 42.3 & 12.9 & 3.6 & 0.8 & 1.1 & 59.9 & 49.2 & 19.1 & 6.7 & 3.4 & 2.6 \\
\hline Prime conforming & 30.3 & 27.7 & 13.7 & 6.2 & 2.2 & 3.7 & 34.4 & 33.1 & 17.0 & 8.3 & 2.7 & 4.8 \\
\hline Prime jumbo & 68.7 & 68.9 & 51.4 & 52.8 & 43.8 & 37.3 & 70.4 & 70.6 & 55.5 & 58.9 & 51.5 & 43.3 \\
\hline Total & 38.5 & 33.6 & 15.6 & 5.8 & 2.3 & 4.0 & 48.9 & 44.6 & 25.6 & 10.5 & 4.0 & 6.1 \\
\hline
\end{tabular}

Panel B: Purchase-Money Mortgages Only

\begin{tabular}{|c|c|c|c|c|c|c|c|c|c|c|c|c|}
\hline & & & Volum & ighted & & & & & Value & ghted & & \\
\hline & 2005 & 2006 & 2007 & 2008 & 2009 & 2010 & 2005 & 2006 & 2007 & 2008 & 2009 & 2010 \\
\hline Government & 8.0 & 3.9 & 3.7 & 2.9 & 1.0 & 2.1 & 8.7 & 4.9 & 4.3 & 3.3 & 1.5 & 2.8 \\
\hline Nonprime & 60.4 & 47.5 & 12.5 & 3.4 & 0.7 & 0.0 & 67.3 & 53.2 & 17.8 & 8.7 & 1.0 & 0.0 \\
\hline Prime conforming & 35.0 & 28.4 & 12.3 & 5.5 & 2.4 & 4.0 & 39.2 & 33.3 & 15.1 & 7.4 & 3.3 & 4.7 \\
\hline Prime jumbo & 72.4 & 67.5 & 49.0 & 46.1 & 35.3 & 43.8 & 73.7 & 68.5 & 53.0 & 52.5 & 44.5 & 43.6 \\
\hline Total (LPS) & 41.8 & 33.4 & 14.1 & 5.0 & 1.8 & 3.2 & 52.3 & 43.3 & 23.3 & 9.0 & 3.8 & 5.5 \\
\hline Total (MIRS) & 34.0 & 24.1 & 10.7 & 5.5 & 1.8 & 1.8 & 38.0 & 28.8 & 15.9 & 9.8 & 3.4 & 1.8 \\
\hline
\end{tabular}

Sources: Lender Processing Services (LPS); Federal Housing Finance Agency, Monthly Interest Rate Survey (MIRS).

Notes: Government mortgages include those insured by the Federal Housing Administration and the U.S. Department of Veterans Affairs.

evolved during the Federal Reserve's Large-Scale Asset Purchase (LSAP) program. Under this program, the Fed purchased roughly $\$ 1.25$ trillion of fixed-rate agency mortgage-backed securities (MBS) between the end of 2008 and the first quarter of $2010 .{ }^{5}$ Since the Fed did not purchase MBS backed by adjustable-rate mortgages, the program could have disproportionately increased the supply of fixed-rate mortgages, thereby reducing the ARM share. We find, however, that this effect could only have been small, since the ARM share was already low before the introduction of the program.

\section{Sources of Mortgage Data}

Our study uses two complementary sources of mortgage data. The first source is the Monthly Interest Rate Survey (MIRS) conducted by the Federal Housing Finance Agency. This survey of mortgage lenders provides loan-level terms and conditions on conventional single-family, fully amortizing "purchase-money" mortgages closed on the last five working days of each month. ${ }^{6}$ (Excluded are loans insured by the Federal Housing Administration, mortgages guaranteed by the U.S. Department of Veterans Affairs, balloon loans, and refinancings.) The survey has been conducted since the 1970s, although it was significantly redesigned in 1991. While

\footnotetext{
${ }^{5}$ Gagnon et al. (2010) present an overview of the LSAP programs and provide evidence that these asset purchases led to economically meaningful reductions in a range of longer term interest rates.

6 "Purchase-money" mortgages are loans used to fund a home purchase rather than to refinance an existing mortgage.
}

participation in the survey is voluntary, the data cover a range of different lender types, including saving associations, mortgage companies, commercial banks, and mutual savings banks. ${ }^{7}$

The second source is a larger loan-level data set, provided by the Applied Analytics divison of Lender Processing Services (LPS). The LPS data draw on information from nearly all the large mortgage servicers and cover about 60 percent of U.S. mortgage originations. Because the LPS data have a shorter history than MIRS and do not have broad market coverage until recent years, our study uses this source only from January 2005 onward.

While MIRS excludes mortgages used to refinance existing loans, LPS includes and identifies both purchase-money loans and refinancings. Nevertheless, if refinancings are omitted from the LPS database, the purchase-only ARM share in the LPS proves to be highly correlated with the ARM share in the MIRS (the correlation coefficient is 97.09 percent) over the period for which both data sources are available, suggesting that they offer a consistent picture of changes in the ARM share over time (Chart 1).

\section{Decomposing the ARM Share}

The composition of mortgage originations has shifted significantly in recent years. The table above breaks down the aggregate trend in the ARM share, based on LPS data, by different mortgage

\footnotetext{
${ }^{7}$ We calculate the MIRS ARM share using the sampling weights provided in the survey, which weight observations across lender types to match market shares reported in the Home Mortgage Disclosure Act data.
} 


\section{U.S. Mortgage Market Terminology}

- Fannie Mae and Freddie Mac: Government-sponsored enterprises (GSEs) that purchase and securitize conforming mortgages. "Fannie" and "Freddie" guarantee the timely payment of principal and interest to investors in agency-issued mortgage-backed securities. On September 7, 2008, Fannie and Freddie were placed in conservatorship by their regulator, the Federal Housing Finance Agency (FHFA). As conservator, the FHFA was given full powers to control the assets and operations of both GSEs.

- Mortgage-backed security (MBS): A fixed-income security whose cash flows derive from a pool of underlying mortgages, residential or commercial. Residential MBS can be divided into agency, government, and nonagency securities. Agency MBS, which are sponsored by Fannie Mae and Freddie Mac, carry a credit guarantee, ensuring that investors do not incur losses in the event of borrower defaults. Government MBS are backed by mortgages with explicit government credit insurance in case of borrower default, through programs from the Federal Housing Administration, the U.S. Department of Veterans Affairs, and others. Nonagency MBS are securitized by private financial institutions and do not carry guarantees against credit losses.

- Prime mortgage: A mortgage loan to a borrower with low credit risk, such as someone with a high credit score, a high down payment, and/or a high income level relative to the scheduled mortgage payments. The term is often used as a synonym for loans that meet underwriting standards set by Fannie Mae and Freddie Mac.

submarkets: government, nonprime, conforming, and jumbo. Loans funded through nonagency MBS markets have declined, whereas government loans insured by the Federal Housing Administration (FHA) and other agencies have increased (see the box for definitions of specialized terms). ${ }^{8}$

The table reveals a sustained and striking decline in the ARM share in each of the four submarkets. This is true whether we consider all mortgage originations, which include refinancings, or only loans used to fund home purchases. In short, the aggregate decline in the ARM share is broadly based rather than driven by individual shifts in the submarkets. The table also documents a consistently higher ARM share in the jumbo market than in the conforming market or government market. ${ }^{9}$

\section{Possible Explanations for Fluctuating ARM Shares}

Academic research has identified a range of factors influencing mortgage choice that may help us understand the low ARM share. These factors can be categorized as demand-side variablesrelating to household preferences_or supply-side variables,

\footnotetext{
${ }^{8}$ The relative market shares of the four submarkets do fluctuate significantly over this period. For example, the market share of government mortgages, such as those insured by the FHA, increases from 3.8 percent of all mortgage originations in 2005 to 27.9 percent in 2009 on a value-weighted basis, while the market share of nonprime originations falls from 23.0 percent to only 2.3 percent over the same period. These shifts largely reflect the collapse of the subprime and Alt-A MBS markets, developments associated with the onset of the financial crisis.

${ }^{9}$ This observation is consistent with the findings of Vickery (2007).
}

- Conforming mortgage: A mortgage that has a principal balance no larger than conforming-loan limits set by the Federal Housing Finance Agency and that also meets other underwriting criteria set by Fannie Mae and Freddie Mac. In 2010, the base conforming-loan limit for single-family homes in the continental United States was $\$ 417,000$. Limits may be higher (generally up to $\$ 729,750$ ) in metropolitan areas with high housing costs.

- Jumbo mortgage: Also known as a "prime jumbo." These mortgages cannot be purchased by Fannie Mae and Freddie Mac because the principal balance exceeds the conforming-loan limit.

- Nonprime mortgage: A loan to a borrower who fails to qualify for a prime loan. Compared with prime borrowers, nonprime borrowers have lower credit scores, lower incomes, or other characteristics that suggest a higher probability of default. Nonprime loans include subprime and Alt-A loans. Alt-A mortgages are generally made to more creditworthy borrowers than subprime loans, although they are more likely to include nonstandard features such as negative amortization.

- Government mortgage: A loan insured against default by a government agency such as the Federal Housing Administration or the U.S. Department of Veterans Affairs. relating to the availability of mortgage credit from lenders. One important demand-side influence is the role of interest rate expectations. If households select a fixed-rate mortgage, their nominal interest rate remains the same until the loan is paid off or refinanced. For an adjustable-rate mortgage, however, only the initial interest rate is known, and the household must form an expectation about the future direction of interest rates.

In the view of some analysts, households are largely myopic. They choose between adjustable-rate and fixed-rate mortgages simply by comparing the initial interest rates they would have to pay on the two contracts. This view would imply that the initial spread between the fixed mortgage interest rate and the ARM interest rate is the primary driver of the ARM share.

Forward-looking households, in contrast, are likely to base their decision on expectations of average future interest payments for adjustable-rate and fixed-rate mortgages. Since interest rates on ARMs are closely tied to future short-term Treasury yields while those on fixed-rate mortgages are strongly related to current long-term Treasury yields, the household's mortgage choice may be related to the term premium on Treasury yieldsthat is, the difference between current long-term Treasury yields and average expected short-term interest rates.

This hypothesis has been formalized and tested by Koijen, van Hemert, and van Nieuwerburgh (2009), who develop a simple theoretical model to show that household mortgage choice should be linked to the current level of the term premium in long-term 
government bond yields. These researchers use different models to estimate the term premium. Most important, they consider a simple rule of thumb by which households extrapolate expectations about future short-term interest rates from average shortterm rates prevailing in the last several years.

This rule-of-thumb measure of the term premium has moved very closely with the ARM share over the past two decades. Models based on alternative term premium measures also correlate with the ARM share. Perhaps surprisingly, the simple spread between fixed mortgage rates and ARM interest rates, or between long- and short-term Treasury yields, is significantly less correlated with the ARM share than are these term premium measures. In our statistical analysis, we examine both rule-ofthumb proxies for household behavior and a model-based measure of the Treasury term premium as potential determinants of the ARM share.

Another demand-side factor influencing mortgage choice is the presence of liquidity constraints. Typically requiring lower initial payments than fixed-rate mortgages, ARMs may be attractive to liquidity-constrained households, such as those whose incomes are low relative to the value of their desired home. Although it is difficult to identify time-series trends in the fraction of liquidity-constrained households, we consider a simple measure of housing affordability as a proxy for these constraints.

A final demand-side hypothesis is that consumer sentiment has simply shifted away from ARMs, perhaps because of negative publicity about interest rate resets on subprime ARMs. While we do not test this hypothesis directly, a finding that the ARM share in recent years has been low relative to normal historical patterns would be consistent with such an explanation.

In addition to these demand-based explanations, several supply-side frictions might also have played a role in mortgage choice, especially during the recent financial crisis. First, primary mortgage rates offered to borrowers are closely tied to secondarymarket yields on mortgage-backed securities. Accordingly, shifts in MBS pricing could alter the relative attractiveness of fixed-rate and adjustable-rate mortgages. We examine this hypothesis by considering term structure variables based on actual primary mortgage rates, rather than Treasury yields. These variables will take into account any increase in spreads between mortgage rates and risk-free rates during the financial crisis.

Second, composition shifts between the conforming and non-conforming mortgage markets may also have influenced mortgage supply. To capture these shifts, we construct a variable that measures the share of "jumbo" mortgage originations — that is, loans that are too large to be eligible for securitization through Fannie and Freddie. Nationally, the size limit for a conforming loan is $\$ 417,000$ for a single-family home, although the Economic Stimulus Act, passed in early 2008, permits higher limits (up to $\$ 729,750$ ) in areas with high housing costs.
Third, financially constrained mortgage lenders may have had less appetite for risk - a condition that would affect both their pricing of different mortgage types and their lending standards. We assess this possibility by examining a variable that measures

Primary mortgage rates offered to borrowers

are closely tied to secondary-market yields on mortgage-backed securities. Accordingly, shifts in $M B S$ pricing could alter the relative attractiveness of fixed-rate and adjustable-rate mortgages.

the average down payment of mortgage borrowers. We also consider a measure of future interest rate volatility as a proxy for the cost to lenders of hedging their exposure to the interest rate and prepayment risk posed by fixed-rate mortgages.

Finally, the Fed's Large-Scale Asset Purchase programdesigned to support the mortgage and housing markets through purchases of agency mortgage-backed securities and other assets - may have shifted demand toward fixed-rate mortgages. ${ }^{10}$ Because all of the mortgage-backed securities purchased were backed by fixed-rate loans, the program may have disproportionately reduced primary fixed rates relative to ARM rates. We investigate this possibility by examining changes in the ARM share around the time of the announcement of the LSAP program.

\section{Determinants of the ARM Share}

In this section, we analyze the historical relationship between the ARM share and a set of variables measuring the demand-side and supply-side factors discussed above. We focus on explaining movements in the purchase-only ARM share from the Monthly Interest Rate Survey, tracked in Chart 1. (We use the share calculated from the MIRS data rather than the share from the Lender Processing Services data because the former is available over a much longer time span.)

We start by defining the explanatory variables used in our analysis. We first consider a variable that simply measures differences in initial borrowing costs between adjustable-rate and fixed-rate mortgages - specifically, the interest rate spread between thirty-year fixed-rate mortgages and one-year ARMs, taken from the Freddie Mac Primary Mortgage Market Survey. We consider next the household rule-of-thumb measure of the term premium as suggested by Koijen et al. (2009). This measure is the difference between the ten-year Treasury yield and the average one-year Treasury yield over the past three years.

\footnotetext{
${ }^{10}$ In its announcement of the program on November 25, 2008, the Federal Reserve indicated that it would purchase up to $\$ 500$ billion of agency MBS; this amount was expanded to \$1.25 trillion in March 2009.
} 
This "trailing" average is intended to be a proxy for household expectations about future short-term interest rates. ${ }^{11}$ When the rule-of-thumb variable is elevated, long-term interest rates are high relative to past short-term rates. At such times, mortgage demand is expected to shift toward ARMs. We label this variable the "Treasury rule of thumb."

We consider also an alternative rule-of-thumb variable based on mortgage rates rather than Treasury yields. This is the difference between current thirty-year fixed-rate mortgage rates and the average one-year ARM rate over the past three years, again as reported in the Freddie Mac Primary Mortgage Market Survey. (Note that this variable differs from the mortgage spread variable, which only compares current interest rates for fixed-rate and adjustable-rate mortgages.) We label this variable the "mortgage rule of thumb." Since this alternative variable is explicitly based on mortgage rates rather than Treasury rates, it will take into account any shifts in mortgage interest rates relative to Treasury yields.

In addition to these backward-looking variables, we consider a model-based estimate of the ten-year Treasury term premium. This estimate is taken from Adrian and Moench (2010), who estimate a statistical model for the U.S. term structure of interest rates. Adrian and Moench show that their model fits the U.S. Treasury yield curve very well in sample and provides good predictions of interest rates out of sample. ${ }^{12}$ The model is based

\section{[Our results suggest] that borrowers attempt to form an expectation about future rates when choosing a mortgage, rather than considering only current rates.}

on predictive regressions and therefore likely provides a more forward-looking estimate of term premia than the rule-of-thumb variables. The computation of the latter, however, requires less sophistication on the part of households.

We also consider the National Association of Realtors (NAR) Affordability Index as a rough proxy for liquidity constraints in home purchases. It is calculated as the ratio of current median family income to the income required to qualify for a medianpriced single-family home loan. We use the Merrill Lynch Option Volatility Estimate (MOVE) Index as a measure of expected Treasury yield volatility.

\footnotetext{
${ }^{11}$ Following Koijen et al. (2009), we also consider a variant of this rule of thumb that is based on the five-year Treasury yield. However, the measure based on the ten-year Treasury yield performs slightly better over our sample period.

12 Their baseline estimates are obtained from a five-factor affine model of the term structure. For an alternative model-based measure of the term premium, we considered an estimate from the three-factor affine model of Kim and Wright (2005). This second measure yielded similar results.
}

\section{Chart 2 \\ Correlation between Independent Variables and ARM Share of Mortgages}

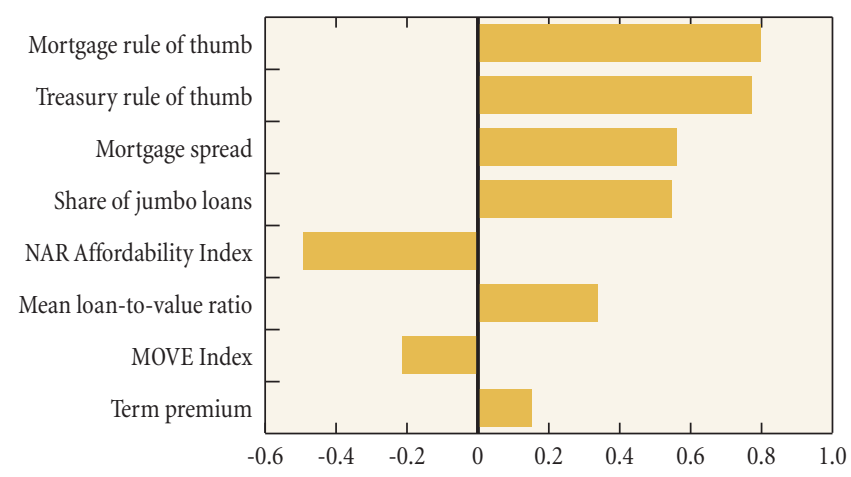

Source: Authors' calculations.

Notes: The ARM share of mortgages is from the Monthly Interest Rate Survey. Data are monthly and cover the period from December 1989 through April 2010. Correlations are measured by the correlation coefficient, which is bounded between -1 (perfect negative correlation) and +1 (perfect positive correlation). "0" indicates no correlation. "NAR" is National Association of Realtors; "MOVE" is Merrill Lynch Option Volatility Estimate.

Finally, we construct two variables from the MIRS data itself: the share of jumbo mortgage originations and the average loan-to-value (LTV) ratio. To calculate the share of jumbo loans, we match each loan in the MIRS data set geographically to the conforming-loan limits in the corresponding metropolitan statistical area. Our expectation is that a decrease in the share of jumbo mortgages should reduce the overall ARM share, because jumbo mortgages are much more likely to be adjustable-rate mortgages than are conforming loans. The jumbo loan share falls sharply at the end of the sample, partly reflecting the increase in conforming-loan limits implemented in 2008. The LTV ratio measures the mortgage amount relative to the appraised value of the property and hence may capture changes in lending standards.

We first calculate the correlation between the ARM share and each of these variables. Since it typically takes a few weeks to close a mortgage contract, we use past values-lagged by one month with respect to the ARM share-of the explanatory (or independent) variables. ${ }^{13}$ These correlations, based on monthly data between December 1989 and April 2010, are presented in Chart 2.

Consistent with the findings of Koijen et al., the Treasury and mortgage rule-of-thumb variables are highly correlated with the ARM share over the past twenty years. ${ }^{14}$ Notably, the explanatory power of these variables is higher than the contemporaneous

\footnotetext{
${ }^{13}$ We also estimated a different specification of our model in which the explanatory variables were lagged by two months. The regression results from this specification were very similar to the results reported here.

14 While we find that the mortgage rule of thumb is the variable most correlated with the ARM share, Koijen et al. (2009) find that the Treasury rule of thumb is more strongly correlated with the ARM share over their sample, which ends in June 2006.
} 
Chart 3

\section{Performance of Model in Explaining ARM Share of Mortgages: December 1989-April 2010}

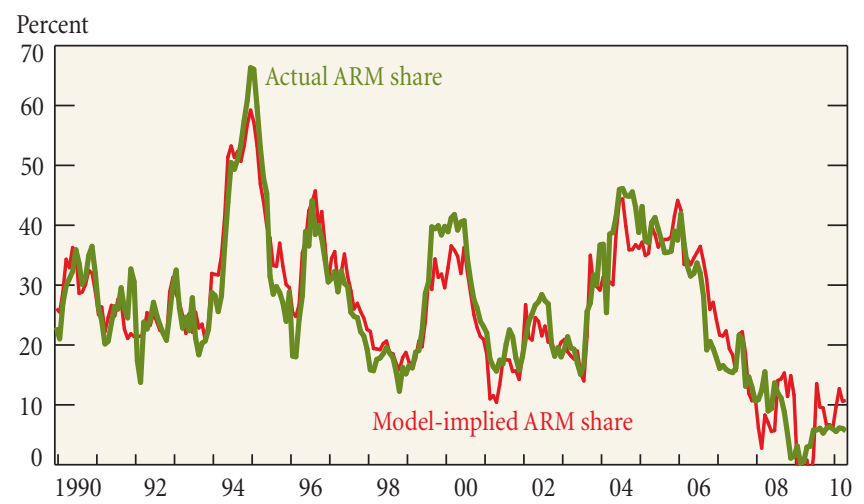

Note: The actual ARM share is from the Monthly Interest Rate Survey.

spread between rates on ARMs and fixed-rate mortgages. This result is consistent with the notion that borrowers attempt to form an expectation about future rates when choosing a mortgage, rather than considering only current rates. A high share of jumbo loans and a low level of housing affordability are also associated with a higher ARM share, although with a somewhat lower correlation. The MOVE Index and the model-based term premium measure are only weakly correlated with the ARM share.

To examine these relationships more formally, we estimate a statistical model of the joint relationship between the ARM share and our set of variables. (Details of the model are described in the appendix.) The results of this analysis, documented in the last column of the appendix table, show that the mortgage rule-ofthumb variable, the mortgage spread, and the jumbo loan share remain highly significant in explaining variation in the ARM share, while the Treasury rule of thumb makes only a small independent contribution to the movement in the ARM share.

The adjusted $\mathrm{R}^{2}$ of the statistical model described in the appendix - a measure of how well the model explains movements in the ARM share over the sample period-is about 86 percent. Hence, the set of explanatory variables we have considered accounts for the historical variation in the ARM share very well. This conclusion is also borne out by Chart 3 , where the model-implied ARM share closely tracks the actual ARM share for much of the December 1989-April 2010 sample period.

\section{Recent Model Performance}

How well does the model explain the decline in the ARM share over the last five years? The ARM share implied by the model drops sharply from the start of 2006 to early 2009, closely matching the decline in the actual data (Chart 4). At that point in 2009, the fitted share based on the model does begin to diverge somewhat from the actual share. Overall, however, our set of demand- and supply-side variables appears to do a good job of explaining the falling ARM share over this period.

\section{Chart 4 \\ Performance of Model in Explaining ARM Share of Mortgages: January 2006-April 2010}

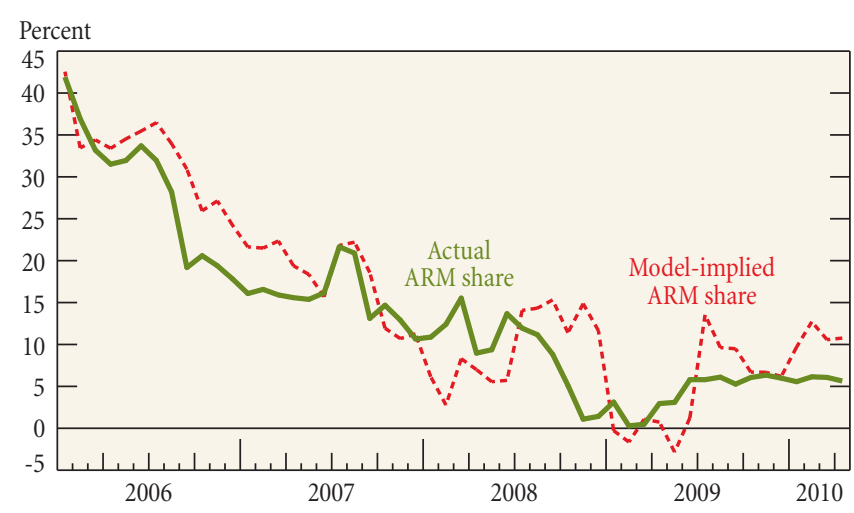

Note: The actual ARM share is from the Monthly Interest Rate Survey.

The contributions of the individual variables to the decline in the fitted ARM share are plotted in Chart $5 .{ }^{15}$ Clearly, the most important determinants of the decline in the ARM share are the two rule-of-thumb variables and the share of jumbo loans. Recall that the Treasury rule of thumb is the difference between current long-term Treasury rates and an average of recent short-term Treasury rates. This variable dropped sharply over the past few

Our model provides persuasive evidence that shifts in the term structure of Treasury yields and in the relative price of fixed-rate versus adjustable-rate mortgages, as well as an increase in the share of conforming mortgages, have contributed to the declining ARM share in recent years.

years, from 2.2 percent in January 2006 to -1.3 percent in January 2009. Thereafter, it began to rise again, reaching 1.7 percent at the end of our sample in April 2010. These large movements partly reflect flight-to-quality effects associated with the financial crisis and the subsequent recovery.

The mortgage rule-of-thumb variable, which is affected by Treasury yields as well as supply and demand factors specific to the mortgage market, experienced similar dynamics over this period. In fact, even as Treasury yields increased in 2009 and 2010, rates on fixed-rate mortgages remained low. In other words, the spread between long-term Treasury yields and fixed mortgage

\footnotetext{
15 Since our regression model is linear, the contribution of each variable is simply the coefficient on that variable in the model, multiplied by the cumulative change in the value of that variable since December 2006.
} 


\section{Contribution of Independent Variables to the Decline in the ARM Share in Recent Years}

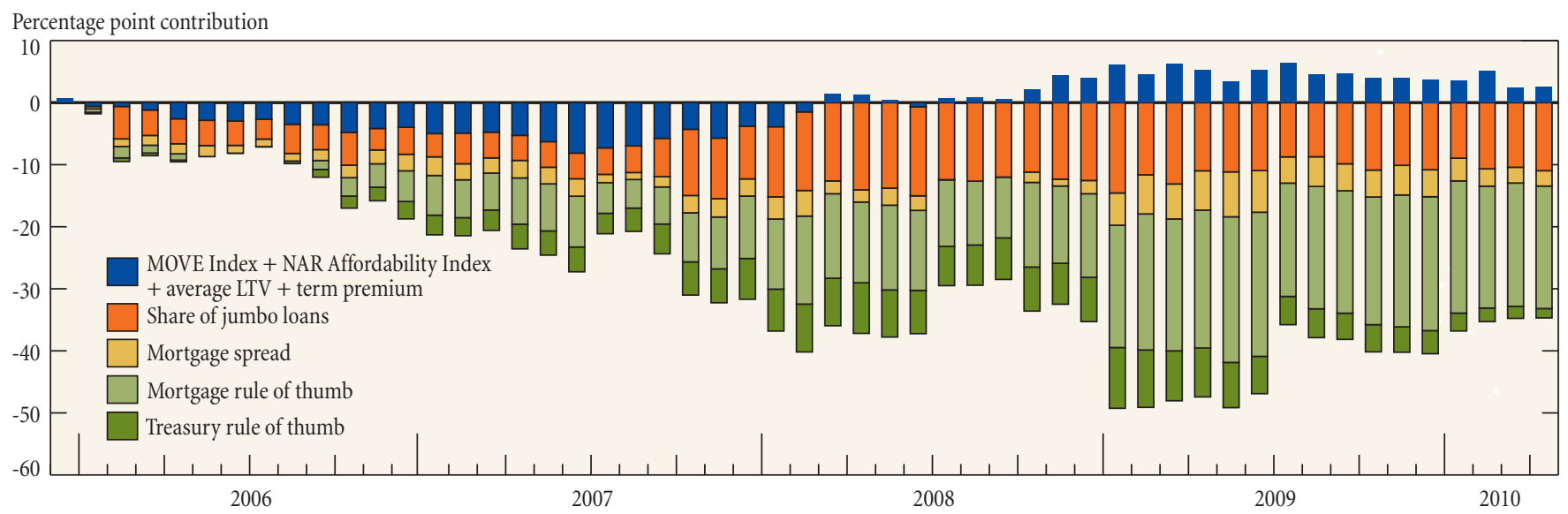

Source: Authors' calculations, based on the statistical model estimated in the appendix.

Notes: "MOVE" is Merrill Lynch Option Volatility Estimate; "NAR" is National Association of Realtors; "LTV” is loan-to-value ratio.

rates declined over this period, helping to keep the ARM share low. As shown in Chart 5, these shifts in the term structure of interest rates appear to be the most important single explanation for the low current ARM share.

The share of jumbo loans has also fallen sharply since the onset of the crisis, from almost a third of all mortgage originations in early 2006 to less than 10 percent in mid-2008 (in mid-2010, it was about 13 percent). This declining share of jumbo loans reflects mainly two factors: 1) the collapse in securitization of nonagency mortgages, including jumbo loans, from late 2007 onward; and 2) a significant increase during February 2008 in the size limit for conforming loans eligible for securitization through Fannie Mae and Freddie Mac. Since the ARM share is significantly higher in the jumbo market, this compositional shift has also contributed to the declining share of adjustable-rate mortgages (Chart 5, orange portion of the bars).

In sum, our model provides persuasive evidence that shifts in the term structure of Treasury yields and in the relative price of fixed-rate versus adjustable-rate mortgages, as well as an increase in the share of conforming mortgages, have contributed to the declining ARM share in recent years.

Nevertheless, we leave open the important question of exactly why the spread between fixed mortgage rates and Treasury bond yields has narrowed so much since the start of 2009. One potential explanation is that financial market conditions have gradually normalized over the past year, leading to a partial unwinding of the flight to quality that sharply reduced Treasury yields in 2008 .

A second explanation is that the supply of Treasury securities relative to that of mortgage-backed securities has increased, owing to significant issuance of new Treasury debt combined with the Federal Reserve's effort to support the housing and mortgage markets by purchasing more than $\$ 1$ trillion of agency mortgage-backed securities to date. ${ }^{16}$ It does not appear, however, that the Federal Reserve's purchase program was a key factor in the decline of ARMs over this period. The ARM share was already extremely low by the time the program was announced in November 2008.

\section{Conclusion}

We have analyzed recent trends in households' mortgage decisions, focusing in particular on the choice between fixedrate mortgages and adjustable-rate mortgages. We document that the market share of ARMs has declined significantly across all segments of the mortgage market in recent years. Using a simple model, we present evidence that this decline in the ARM share can largely be accounted for by factors that explain mortgage choice in earlier periods-in particular, measures of the relative borrowing costs for fixed-rate and adjustable-rate mortgages. Supply-side factors, especially the increasing share of the conforming mortgage market, are also important in accounting for the fall in the ARM share over this period.

While the variables included in our model account for most of the recent variation in the ARM share, other factors related to the financial crisis may also have had some effect on household mortgage choice in recent years. Among these factors, the implementation of the Federal Reserve's MBS purchase program does not appear to be a dominant explanation for the fall in the ARM share, since this share was already at historic lows before the announcement of the program in November 2008.

\footnotetext{
${ }^{16}$ For more on the impact of the Federal Reserve's MBS purchases, see, for example, Gagnon et al. (2010) and Stroebel and Taylor (2009).
} 


\section{The Econometric Model}

The simple correlations reported in Chart 2 cannot capture the multiple joint relationships that may exist between the set of explanatory variables and the ARM share. Nor can they assess the likelihood that the correlation is simply due to chance, rather than an underlying economic relationship. To address these concerns-albeit in a partial way-we estimate univariate and multivariate linear regression models of the determinants of the ARM share as a function of the potential determinants of mortgage choice considered here. ${ }^{\text {a }}$ The results are presented in the table below. For each variable, the slope coefficient reported in the table reveals the effect of a one-unit change in the variable on the predicted ARM share.
The two rule-of-thumb variables appear to be the most important determinants of the ARM share, as measured both by their $\mathrm{R}^{2}$ in the univariate specifications and by their contribution to the multivariate model. The adjusted $\mathrm{R}^{2}$ for the multivariate specification is 0.86 , suggesting that our set of variables captures most of the variation in the ARM share over the sample period. The mortgage rule-of-thumb variable alone has an $R^{2}$ of 0.63 .

We also experimented with versions of our regression model that exclude supply-side variables such as the share of jumbo loans. If we exclude these variables, the model is less effective in explaining the recent decline in ARMs - an outcome that confirms the importance of these variables for understanding the currently low ARM share.

\section{Determinants of the ARM Share: Regression Results}

Dependent Variable: MIRS Purchase-Only ARM Share

(1)

(2)

(3)

$(4)$

(5)

(6)

(7)

$(8)$

(9)

\begin{tabular}{|c|c|c|c|c|c|c|c|c|c|}
\hline $\begin{array}{l}\text { Mortgage spread } \\
\quad \text { (fixed-rate minus adjustable-rate) }\end{array}$ & $\begin{array}{l}9.38^{* * *} \\
{[3.34]}\end{array}$ & & & & & & & & $\begin{array}{l}6.22^{* * *} \\
{[4.96]}\end{array}$ \\
\hline \multirow[t]{2}{*}{ Treasury rule of thumb } & & $9.21^{* * *}$ & & & & & & & $2.65^{* *}$ \\
\hline & & {$[8.88]$} & & & & & & & {$[2.42]$} \\
\hline \multirow[t]{2}{*}{ Mortgage rule of thumb } & & & $11.10^{* * *}$ & & & & & & $8.29^{* * *}$ \\
\hline & & & {$[9.13]$} & & & & & & {$[5.04]$} \\
\hline \multirow[t]{2}{*}{ Term premium (Adrian-Moench) } & & & & 2.34 & & & & & -0.42 \\
\hline & & & & {$[0.90]$} & & & & & {$[-0.51]$} \\
\hline \multirow[t]{2}{*}{ NAR Affordability Index } & & & & & $-0.40^{* *}$ & & & & 0.02 \\
\hline & & & & & {$[-5.35]$} & & & & {$[0.34]$} \\
\hline \multirow[t]{2}{*}{ MOVE Index } & & & & & & -0.11 & & & 0.04 \\
\hline & & & & & & {$[-1.24]$} & & & {$[1.44]$} \\
\hline \multirow[t]{2}{*}{ Share of jumbo loans } & & & & & & & $1.58^{* * *}$ & & $0.65^{* * *}$ \\
\hline & & & & & & & [5.36] & & {$[3.85]$} \\
\hline \multirow[t]{2}{*}{ Average loan-to-value ratio } & & & & & & & & $2.07^{\star}$ & $-1.38^{* * *}$ \\
\hline & & & & & & & & [1.67] & {$[-4.24]$} \\
\hline Adjusted $R^{2}$ & 0.311 & 0.594 & 0.634 & 0.019 & 0.240 & 0.042 & 0.295 & 0.109 & 0.861 \\
\hline Number & 245 & 245 & 245 & 245 & 245 & 245 & 245 & 245 & 245 \\
\hline
\end{tabular}

Notes: Specifications (1) through (8) report slope coefficients for univariate time-series regressions. Specification (9) reports slope coefficients for a multivariate timeseries regression. All specifications use Newey-West standard errors with twelve lags. Data are monthly and cover the period from December 1989 through April 2010. The $t$-statistics are reported in brackets. Means and standard deviations for each variable used in the multivariate regression are as follows: Treasury rule of thumb $(0.9,1.0)$, mortgage rule of thumb $(1.4,0.9)$, mortgage spread $(1.7,0.7)$, term premium $(1.7,0.8)$, Merrill Lynch Option Volatility Estimate (MOVE) Index (103.0, 24.1), National Association of Realtors (NAR) Affordability Index (127.3, 15.3), mean loan-to-value ratio (78.1, 2.0), and share of jumbo loans (20.4, 4.3).

${ }^{*} \mathrm{p}<0.1$.

${ }_{* *}^{*} \mathrm{p}<0.05$.

$* * * \mathrm{p}<0.01$.

${ }^{\text {a }}$ Note that, by construction, the share of ARMs is bounded between zero and one. This censored support of the dependent variable in our regressions might introduce a bias in the parameter estimates. As a robustness check, we estimate the same set of regressions as in the appendix table, using a model in which the ARM share is transformed using the inverse normal cumulative density function. The results of these regressions are very similar to those of the linear specifications documented above, so we do not report them here. 


\section{References}

Adrian, Tobias, and Emanuel Moench. 2010. "Pricing the Term Structure with Linear Regressions." Federal Reserve Bank of New York Staff Reports, no. 340, July. Debelle, Guy. 2004. "Household Debt and the Macroeconomy." BIS Quarterly Review, March: 51-64.

Gagnon, Joseph, Matthew Raskin, Julie Remache, and Brian Sack. 2010."LargeScale Asset Purchases by the Federal Reserve: Did They Work?” Federal Reserve Bank of New York Staff Reports, no. 441, March.

International Monetary Fund. 2004. "Three Current Policy Issues." Chap. 2 in World Economic Outlook: The Global Demographic Transition. September. Available at http://www.imf.org/external/pubs/ft/weo/2004/02.

Kim, Don, and Jonathan H. Wright. 2005. "An Arbitrage-Free Three-Factor Term Structure Model and the Recent Behavior of Long-Term Yields and DistantHorizon Forward Rates." Board of Governors of the Federal Reserve System, Finance and Economics Discussion Series, no. 2005-33, August.
Koijen, Ralph, Otto van Hemert, and Stijn van Nieuwerburgh. 2009. "Mortgage Timing." Journal of Financial Economics 93, no. 2 (August): 292-324.

Miles, David. 2004. “The U.K. Mortgage Market—Taking a Longer-Term View: Final Report and Recommendations." Report Commissioned by HM Treasury, United Kingdom, March.

Mishkin, Frederic. 2007. "Housing and the Monetary Transmission Mechanism." Board of Governors of the Federal Reserve System, Finance and Economics Discussion Series, no. 2007-40, August.

Stroebel, Johannes, and John Taylor. 2009. “Estimated Impact of the Fed's Mortgage-Backed Securities Purchase Program.” Unpublished paper, Stanford University.

Tsatsaronis, Kostas, and Haibin Zhu. 2004. "What Drives House Price Dynamics: Cross-Country Evidence." BIS Quarterly Review, March: 65-78.

Vickery, James. 2007. “Interest Rates and Consumer Choice in the Residential Mortgage Market." Unpublished paper, Federal Reserve Bank of New York.

\section{OTHER FEDERAL RESERVE BANK OF NEW YORK PUBLICATIONS RELATING TO THE MORTGAGE MARKET}

A Private Lender Cooperative Model for Residential Mortgage Finance

Toni Dechario, Patricia Mosser, Joseph Tracy, James Vickery, and Joshua Wright

Federal Reserve Bank of New York Staff Reports, no. 466

August 2010

This study presents a set of six design principles for the reorganization of the U.S. housing finance system and applies them to one model for replacing Fannie Mae and Freddie Mac that has so far received frequent mention but little sustained analysis - the lender cooperative utility. The authors discuss the pros and cons of such a model and propose a method for organizing participation in a mutual loss pool and an explicit, priced government insurance mechanism. They also discuss how these principles and this model are consistent with preserving the "to-beannounced," or TBA, market-particularly if the fixed-rate mortgage remains a focus of public policy.

\section{Companion Video}

Joe Tracy and Joshua Wright assess the merits and drawbacks of the government-sponsored enterprises Fannie Mae and Freddie Mac, outline design principles for a reformed home finance system, and weigh the pros and cons of replacing Fannie Mae and Freddie Mac with a lender cooperative. Available at http://www.newyorkfed.org/research/video _interviews.html
TBA Trading and Liquidity in the Agency MBS Market James Vickery and Joshua Wright Federal Reserve Bank of New York Staff Reports, no. 468 August 2010

Most mortgages in the United States are securitized through the agency mortgage-backed securities (MBS) market. These securities are generally traded on a "to-be-announced," or TBA, basis. This trading convention significantly improves agency MBS liquidity, leading to lower borrowing costs for households. Evaluation of potential reforms to the U.S. housing finance system should take into account the effects of those reforms on the operation of the TBA market.

\section{MBS Ratings and the Mortgage Credit Boom}

Adam Ashcraft, Paul Goldsmith-Pinkham, and James Vickery Federal Reserve Bank of New York Staff Reports, no. 449 May 2010

The authors study credit ratings on subprime and Alt-A mortgagebacked securities (MBS) deals issued between 2001 and 2007, the period leading up to the subprime crisis. They find that the amount of credit enhancement increases with the amount of mortgage credit risk (measured either ex ante or ex post), suggesting that ratings contain useful information for investors. However, the authors also find evidence of significant time variation in risk-adjusted credit ratings, including a progressive decline in 
standards around the MBS market peak between the start of 2005 and mid-2007. They observe, conditional on initial ratings, underperformance (high mortgage defaults and losses and large rating downgrades) among deals with observably higher-risk mortgages based on a simple ex ante model and deals with a high fraction of opaque low-documentation loans. These findings hold over the entire sample period, not just for the deal cohorts most affected by the crisis.

\section{Subprime Mortgage Pricing: The Impact of Race, Ethnicity, and Gender on the Cost of Borrowing \\ Andrew Haughwout, Christopher Mayer, and Joseph Tracy Federal Reserve Bank of New York Staff Reports, no. 368 April 2009}

Some observers have argued that minority borrowers and neighborhoods were targeted for expensive credit in 2004-06, the peak period for subprime lending. To investigate this claim, this study takes advantage of a new data set that merges demographic information on subprime borrowers with information on the mortgages they took out. In a sample of more than 75,000 adjustable-rate mortgages, the authors find no evidence of adverse pricing by race, ethnicity, or gender in either the initial rate or the reset margin. Indeed, if any pricing differential exists, minority borrowers appear to pay slightly lower rates, as do those borrowers in Zip codes with a larger percentage of black or Hispanic residents or a higher unemployment rate. Mortgage rates are also lower in locations that previously had higher rates of house price appreciation. These results suggest some economies of scale in subprime lending. Yet there are important caveats: the authors are unable to measure points and fees at loan origination, and the data do not indicate whether borrowers might have qualified for less expensive conforming mortgages.

\section{Subprime Mortgage Lending in New York City: Prevalence and Performance \\ Ebiere Okah and James Orr \\ Federal Reserve Bank of New York Staff Reports, no. 432 February 2010}

Subprime mortgage lending expanded in New York City between 2004 and mid-2007, and delinquencies on these subprime loans have been rising sharply. The authors use a rich, loan-level data set of the city's outstanding subprime loans as of January 2009 to describe the main features of this lending and to model the performance of these loans. The subprime loans represent a smaller share of total housing units in the city than is true nationwide. In addition, they are found to be clustered in neighborhoods where average borrower credit quality is low and, unlike prime mortgage loans, where African-Americans and Hispanics constitute relatively large shares of the population. The authors estimate a model of the likelihood that these loans will become seriously delinquent and find a significant role for credit quality of borrowers, debt-to-income and loan-to-value ratios at the time of loan origination, and estimates of the loss of home equity.

\section{ABOUT THE AUTHORS}

Emanuel Moench is an economist in the Capital Markets Function and James Vickery an economist in the Financial Intermediation Function of the Federal Reserve Bank of New York. Diego Aragon, an assistant economist in the Financial Intermediation Function at the time this article was written, is now pursuing a master's degree in Public Affairs at Princeton University.

Current Issues in Economics and Finance is published by the Research and Statistics Group of the Federal Reserve Bank of New York. Linda Goldberg and Erica L. Groshen are the editors.

Editorial Staff: Valerie LaPorte, Mike De Mott, Michelle Bailer, Karen Carter

Production: Carol Perlmutter, David Rosenberg, Jane Urry

Subscriptions to Current Issues are free. Write to the Media Relations and Public Affairs Department, Federal Reserve Bank of New York, 33 Liberty Street, New York, N.Y. 10045-0001, or send an e-mail to pipubs@ny.frb.org. Back issues of Current Issues are available at http://www.newyorkfed.org/research/current_issues/.

The views expressed in this article are those of the authors and do not necessarily reflect the position of the Federal Reserve Bank of New York or the Federal Reserve System. 